ISSN 1991- 8690

Website: http://jsci.utq.edu.iq
الترقيم الدولي 8690 - 1991

Email: utjsci@utq.edu.iq

\title{
Antibacterial action of five type of honey sample against three common pathogens isolate from surgical wound \\ Elham jwad kadhem bilale
}

\begin{abstract}
$\underline{\text { Abstract }}$
The aim of the present study was to assess the in vitro antibacterial activity of honey on certain potentially pathogenic bacterial isolates., antibacterial activities of five honey samples collected from abu- alyakdan apiarist were all tested against three clinical pathogens isolate from surgical wound such as Staphylococcus aureus and Klebsiella pneumoniae. These honey samples were compared with standard antibiotics like Ampicillin, Tetracycline, ciprofloxacin. The antibacterial activity was tested using Kirby-Bauer's method for antibiotics and well diffusion method for honey samples. The honey samples were tested at concentrations of $(25 \%, 50 \%, 75 \%)$. The all sample of honey showed distinct bacterial inhibitory effect in vitro at honey concentrations of $50 \%$ and above on the various tested bacteria. No growth inhibition effect was observed at $25 \%$ concentration of all honey type against Kl.pneumoniae except mountaineer and eucalyptus honey which showed more activity against the three tested isolat. The study shows that honey more active than antibiotics, has certain organisms sensitive to it, and provides alternative therapy against certain bacteria and is also shown to have antibacterial action against a broad spectrum of bacteria, both gram- positive and gram-negative bacteria.
\end{abstract}

\section{Introduction}

Development of antibiotic resistant bacteria continues to be of major health concern world-wide (Hseuh,2003). Antimicrobial agents are essentially important in reducing the global trouble of infectious diseases. However, as resistant pathogens develop and spread, the effectiveness of the antibiotics is diminished. This type of bacterial resistance to the antimicrobial agents poses a very serious threat to public health, and for all kinds of antibiotics, including the major last-resort drugs, the frequencies of resistance are increasing worldwide[Levy SB(2004), Mandal S(2009)].this compels the search for alternate antibacterial agents have received much attention, after extensive research was conducted to investigate antibacterial properties and applications in the field of biomedicine and pharmaceutics. The honey has been used from ancient times as a method of accelerating wound healing[ Van den Berg AJ,(2008)]. and the potential of honey to assist with wound healing has been demonstrated repeatedly[,(Molan PC, Simon A,2008). Honey is gaining acceptance as an agent for resulting from burns and wounds (Cooper RA,2002) The healing properties of honey can be ascribed to the fact that it offers antibacterial activity, maintains a moist wound environment that promotes healing, and has a high viscosity which helps to provide a protective barrier to prevent infection( Lusby PE,2005). There are many reports of honey being very effective as dressing of wounds, burns, skin ulcers and inflammations; the antibacterial properties of honey speed up the growth of new tissue to heal the wound( Lusby PE,2002), The application of honey can promote the healing in infected wounds that do not respond to the treatment of ulcers, bed sores and other skin infections. (Al-Waili NS, 2005).So it is necessary to isolate active compounds from honey which can be used beyond conventional antibiotic therapy (Molan). Honey is a thick sweet liquid made by bees from the nectar of flowers, Honey is essentially a highly concentrated water solution of two sugars, dextrose and laevulose, with small amounts of at least 22 other more complex sugars, Many other substances also occur in honey, but the sugars are by far the major components. The principal physical characteristics and behavior of honey are due to its sugars, but the minor constituents - such as flavouring materials, pigments, acids, and minerals are largely responsible for the differences among individual honey types (Molan, 1992a). The ability of honey to kill microorganisms has been attributed to its high osmotic effect, high acidic nature, hydrogen peroxide concentration and its phytochemical nature, which include its content of peroxides, amylose, fatty acids, phenols, ascorbic acid, terpenes, benzyl alcohol and benzoic acid (Bogdanov, (1989); Molan, 1992a). However, large variations in the in vitro antibacterial 
activity of various types of honey have been reported and thus hampered its acceptance in modern medicine (Kwakmann, 2008). The production and type of honey produced by honeybees is dependent on the natural vegetative flowers blooming in different seasons. Thus the flowers from which bees gather nectar to produce honey may contribute to the difference in the antimicrobial activities. Molan (1992a) Glucose oxidase originates from the hypopharyngeal glands of honeybee. (Taormina, 2001). When hydrogen peroxide is removed by adding catalase, some honeys still show significant antibacterial activity (Allen KL,2000) and this activity is referred to as non-peroxide antibacterial activity. The non-peroxide factors of honeys include lysozyme, phenolic acids and flavonoids (. Taormina 2001). All these factors give honey unique properties such as wound of scarring and stimulation of angiogenesis as well as tissue granulation and epithelium growth. Laboratory studies and clinical trials have shown that honey is an effective broadspectrum antimicrobial agent. Honey has been reported to have inhibitory effect on several bacteria including aerobes and anaerobes, Gram-positive and Gramnegative and is effective against methicillin resistant Staphylococcus aureus (MRSA), Escherechia coli Klebsiella pneumonia as reported by Allen et al. (2000) and Kingsley (2001). Our study is to determine the antibacterial activity of fourtype of local honey samples include (kalibtus,sider,bersem, koktel) hony against three type of clinical pathogens including gram positive bacteria such as stafillococcus aureus, and gram negative bacteria such Escherechia coli,klebsiella pneumonia isolate from various clinical sample .

\section{Materials and Methods}

five honey samples (HS1, HS2,HS3,HS4,Hs5) were collected from local(Abu- alyakdan) apiarists in Al-najaf Al- ashraf city These 5 samples were harvested from honey bee nests of kaliptus , sider, brsem , and koktel tree Honey and Montale honey samples were stored at $4^{\circ} \mathrm{C}$ in the dark until analyzed. For the antibacterial tests honey samples were used at 25, 50 and $75 \%$ concentration.

\section{Standard drugs}

A concentration of $30 \mu \mathrm{g} / \mathrm{disc}$ of Ampicillin, Tetracycline and ciprofloxasin (HIMEDIA) was employed for S. aureus and K.pneumoniae ,Escherechia coli isolated from surgical wound.

\section{Antimicrobial Susceptibility}

The antimicrobial activity of different samples of honey against different pathogens was tested using
Kirby Bauer's method (. Allen KL, Molan PC, Reid GM. A survey of the antibacterial activity of some New Zealand honeys. J Pharm Pharmacol 1991; 43: 817822.15) for antibiotics and well diffusion method for honey sample. Test materials were prepared by diluting each honey sample (HS1, HS2, HS3, HS4,Hs5) in sterilized, double distilled water at different dilutions (concentration) 25\%, 50\%, 75\%, Muller Hinton Agar (MHA) plates were prepared. A loop full $(4 \mathrm{~mm}$ in diameter) of the prepared bacterial suspensions ( $1 \mathrm{x}$ $104 \mathrm{CFU} / \mathrm{ml}$ ) were separately applied to the centre of a sterile Muller Hinton agar plate and spread evenly using a sterile cotton wool. Wells were made on the inoculated plate using a sterile well borer $(6 \mathrm{~mm}$ in diameter). Then 100 micro liters of different concentrations of honey were dispensed and inoculated at $37^{\circ} \mathrm{C}$ for 20 hours and observed for various zones of inhibition.

\section{Results}

The results for various activities are tabulated in tables ( 1,4$)$, and fig $(1,3)$ When comparing the activity of antibiotics beside honey, the maximum zone of inhibition for honey is grater when compared to the maximum value for antibiotics. The results shown by honey samples in relation to staphylococcus aureus may be important, which given that in recent decades there has been marked increase in difficulty to treat skin and underlying tissue infections associated with st. aureus (Halconjet al,2004) it has been informed that st. aureus has developed resistance to several antibiotics and that it is the principle contaminant agent in many clinical infections (morenoj et al ,2005).

Table (1) Antibacterial Activity of five honey type in concentration of $75 \%$ against three type of clinical isolates

\begin{tabular}{|c|c|c|c|c|c|}
\hline \multicolumn{5}{|c|}{$\begin{array}{l}\text { Diameter of inhibition zone (mm)to five hony samples inconcentration } \\
\qquad \text { of } 75 \%\end{array}$} & \multirow[t]{2}{*}{ isolates } \\
\hline \multicolumn{5}{|c|}{ eucalyptus sider mountaineer brsem koktel } & \\
\hline 25 & 48 & 45 & 38 & 34 & E. coli \\
\hline 20 & 25 & 28 & 20 & 25 & Kl. pneumoniae \\
\hline 40 & 44 & 47 & 40 & 45 & S.aureus \\
\hline
\end{tabular}


Table (2) Antibacterial Activity of five honey type in concentration of $50 \%$ against three type of clinical isolates

\begin{tabular}{|c|c|c|c|c|c|}
\hline \multicolumn{6}{|c|}{$\begin{array}{c}\text { Diameter of inhibition zone (mm)to five hony samples in } \\
\text { concentration of } 50 \%\end{array}$} \\
\cline { 1 - 4 } \\
\hline eucalyptus & sider & mountaineer brem koktel & 1 & \\
\hline 22 & 28 & 30 & 25 & 28 & E.coli \\
\hline r & 10 & 20 & r & 10 & Kl.pneumoniae \\
\hline 34 & 30 & 38 & 28 & 30 & S.aureu \\
\hline
\end{tabular}

Table (3) Antibacterial Activity of five honey type in concentration of $25 \%$ against three type of clinical isolates

\begin{tabular}{|r|r|r|r|c|c|}
\hline \multicolumn{7}{|c|}{ Diameter of inhibition zone (mm)to five hony samples } & \multirow{2}{*}{ isolates } \\
inconcentration of $25 \%$ \\
eucalyptus \\
sider & mountaineer & brsem & \\
\hline $\mathrm{r}$ & 10 & 20 & 10 & $\mathrm{r}$ & E.coli \\
\hline $\mathrm{r}$ & $\mathrm{r}$ & 8 & $\mathrm{r}$ & $\mathrm{r}$ & Kl.pneumoniae \\
\hline 18 & 20 & 24 & 14 & 18 & S.aureus \\
\hline
\end{tabular}

Table (4) Antibacterial Activity ofthree type of antibiotics against three type of clinical isolates

\begin{tabular}{||c|c|c|c|}
\hline \multicolumn{3}{|c|}{ Antibiotics $(30 \mu \mathrm{g} /$ disc $)$} & \multirow{2}{*}{ isolates } \\
\cline { 1 - 3 } Amp & Tet & \\
\hline $\mathrm{r}$ & 10 & 10 & E.coli \\
\hline $\mathrm{r}$ & $\mathrm{r}$ & $\mathrm{r}$ & Kl.pneumoniae \\
\hline $\mathrm{r}$ & 18 & 20 & S.aureus \\
\hline
\end{tabular}

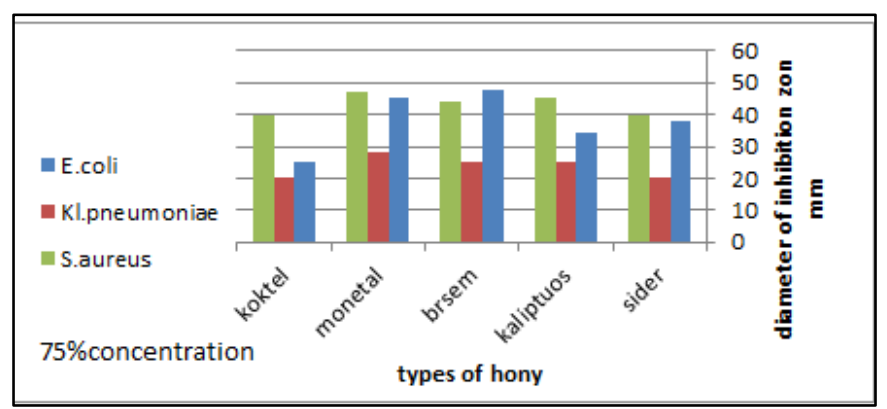

Fig1 Antibacterial Activity of five honey type in concentration of $75 \%$ against three type of clinical isolates

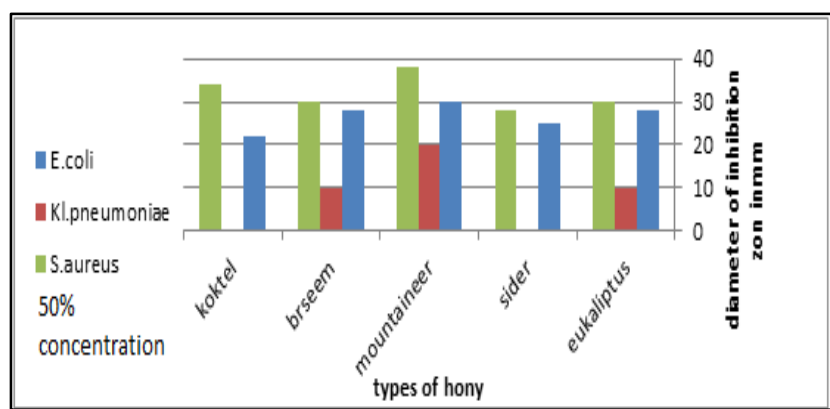

Fig 2 Antibacterial Activity of five honey type in concentration of $50 \%$ against three type of clinical isolates

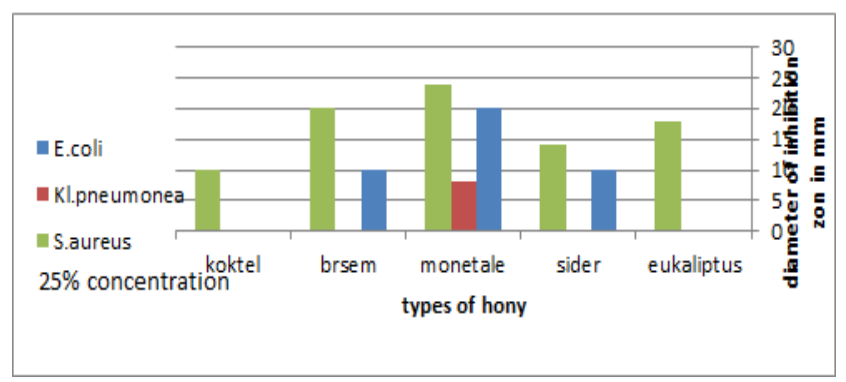

(Fig 3) Antibacterial Activity of five honey type in concentration of $25 \%$ against three type of clinical isolates

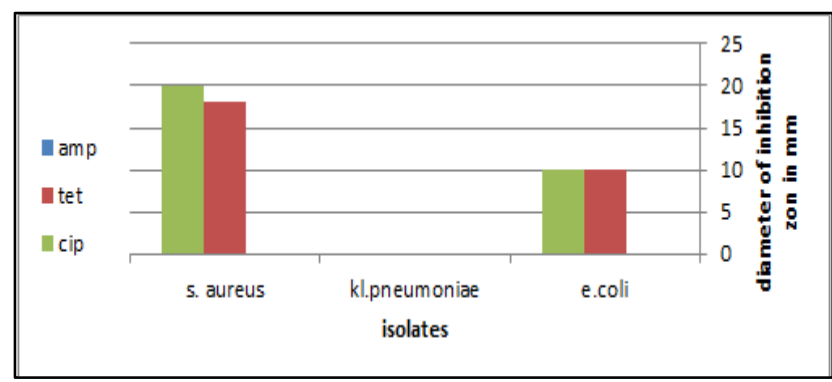

(Fig 4) Antibacterial Activity of three type of antibiotics against three type of clinical isolates

In this study, The results of the susceptibility test of five honey samples against three test organism include (s.aureus, e.coli .k.pneumoniae) were different in particular. All the test organisms were sensitive to $(75 \%$ and half-diluted 50\%) concentrations of all honey samples, Klebsiella pneumoniae showed more resistant to $(25 \%)$ concentration of brseem, sider, eukaliptus and koktel hony samples,may be due to the permeability barrier afforded by its outer membrane, while the mountaineer honey sample showed more activity against the same isolate of $\mathrm{k}$. pneumonia in all concentration. There was no evidence of growth 
inhibition in the cases of $25 \%$ concentration with both gram negative bacteria E coli and k.pneumoniae in twq honey type(euokaliptus,koktel) on the other hand $\mathrm{s}$. aureus showed more sensitivity for all three concentration $(25 \%, 50 \%, 75 \%)$ of all five honey with some variation on the diameter of inhibition zone for all sample but, however, concentrations up to $25 \%$, yet it was confirmed that the honey samples still contained some antimicrobial properties at that concentration as it was able to inhibit the growth of other test organisms at that same concentration. Staphylococcus aureus Escherichia coli, The inhibitory effect of all honey samples was highest on Staphylococcus aureus and followed by Escherichia coli, has always been employed in many microbiological evaluations of honey because of its high sensitivity [Cooper, R.A. (1999),.Molan, P.C., (2002)]. The reason for this unusual sensitivity is not known. It may be related to the sensitivity of Staphylococcus aureus to acidic environment of natural honey [Molan, P.C., (2002), Another area of interest is the ability of the five honey samples to exert antimicrobial effects on E. coli and klebsiella pneumoniae which were resistant to Tetracycline, a and its inability to inhibit the growth of E.coli, k.pneumoniae could be as a result of misuse and abuse of drug, as Tetracycline is one of the common antibiotics that have been greatly abused. The pattern of inhibition of growth of by the all honey samples was the more than the standard antibiotics. For instance, $75 \%$ concentration of all five honey sample gave a zone of inhibition which was more larger, These results suggest that the honey samples used contained some bio-components whose antimicrobial activities against E. coli are highly comparable with those of these two antibiotics. The results of this study are in aggrement with a number of previous studies with a number of previous studies that have been reported by different researchers in the past Antimicrobial activity of honey is thought to be due to some physicochemical properties such as high content of reducing sugars, high viscosity, high osmotic pressure, low $\mathrm{pH}$, low water activity (low protein content and hydrogen peroxide [,Radwan, S.S.,1984 ;.Bergman,A.Yanai 1983]. Also, Radwan , attributed the antibacterial activity to specific chemicals in honey. The nature of these chemicals and the mechanisms of their action, and High Performance Liquid Chromatography (HPLC) have confirmed the presence of fatty acids, lipids amylases and ascorbic acids in pure honey [ Mohrig,W. and Messner, R. (1968);.Bogdanov, S., 1984]. It has been reported that honey contains lysozyme, a well known antibacterial agent [.Bogdanov, S., (1989)]. However, in another study no lysozyme activity was found [.Nzeako and Hamdi (2000)]. The antibacterial flavonoid pinocembrin is present in honey, but its concentration and contribution to honey's non-peroxide antibacterial activity is small [Mogessie, A. (1994).]. Nzeako and Hamdi [Cooper, R.A., Molan, P.C. and Harding, K.G. (1999).] in their studies of six commercial honeys found that inhibition. The flora source determines attributes of natural products such as honey making the composition highly variable [Molan, P.C. andCooper,V. (2000)]The present study showed that the honey inhibited the gram positive bacteria at lower concentration, than gram negative bacteria which requires higher concentration The variation of susceptibility of the tested microorganisms could be attributed to their intrinsic properties that are related to the permeability of their cell surface to the honey sample. It has been proposed that the mechanism of the antimicrobial effects involves the inhibition of various cellular processes, followed by an increase in plasma membrane permeability and finally leads to leakage of ions from the cells(Walsh SE,2003)The effectiveness of honey depends on differences in chemical composition, bee species and geographical region(Miorin PL,2003) The concentration of honey might be varied in the inhibition of pathogenic organisms, thereby making honey a superior antibacterial agent compared to several known and. currently prescribed antibiotics.

\section{Conclusion}

Over use of antibiotics leads to side effects and also a major factor for the emergence of multidrug resistant microorganisms. So honey can be used as an excellent alternate to combat the further spread of multidrug resistant microorganisms. Further research is necessary to isolate the active compounds from these honey samples and to check the antibacterial activity. However, pharmacological standardization and clinical evaluation on the effect of honey and its active components standardization and clinical evaluation on the effect of honey and its active components standardization and clinical evaluation on the effect of honey and its active components related to the tested bacterial species. The wider availability of honey in rural areas provides its utilization for certain diseases.

The present study has been shown that the potency of the antibacterial activity of different type of hony can vary very markedly. The number of variable factors involved makes it impossible to predict with any certainty that a particular honey will have a high 
antibacterial activity. Because of this, honeys purveyed for therapeutic use should be assayed for their antibacterial activity as a form of quality assurance. As a further precaution against possible loss of antibacterial activity, honeys with high activity should not be blended with honey of low activity: a honey with low activity could well have components present that destroy antibacterial activity. Loss of antibacterial activity on exposure to light is another important consider-ation. Because there is little certainty about which floral sources give honeys that are sensitive to light, and because some can be very sensitive, it is important that honey intended for therapeutic use be protected from light to prevent possible reduction of its antibacterial activity. For retail sale it could well be packaged in brown glass containers like other medical products.

\section{Refrences}

Allen KL, Molan PC, Reid GM. A survey of the antibacterial activity of some

Allen KL, Molan PC, Reid GM. A survey of the antibacterial activity of some New Zealand honeys. J Pharm Pharmacol 1991; 43: 817-822.

Al-Waili NS, Akmal M, Al-Waili FS, Saloom KY, Ali A. The antimicrobial potential of honey from United Arab Emirates on some microbial isolates. Med Sci Monitor 2005; 11: 433-438.

and negative bacteria. J. Appl. Microbiol 2003; 94: 24024722)

antioxidant power. Int. J. Food Microbiol 2001; 69: 217-225.

as a promising antimicrobial. Am. J. Infect. Control 2004; 32: 402-408.

Biedenbach DJ, Moet GJ, Jones RN. Occurrence and antimicrobial resistance

Bilal AN, Molan PC, Sallal AK. 1998. Antimicrobial activity of honey on selected microorganisms: A preliminary study. Biomed. Res. (India). 9:51-54.

Bogdanov S. 1989. Characterization of antibacterial substance in honey. Lebensm Wiss. Technol., 17(2):74-76.

Bogdanov S. Nature and origin of the antibacterial substances in honey. Lebensm-

Bogdanov, S., (1984). Characterisation of antibacterial substances in honey. LebensmittelWissenschaft undTechnologie, 17: 74-76.

borne pathogens as influenced by the presence of hydrogen peroxide and level of
Ceyhan N, Ugur A. 2001. Investigation of in vitro antimicrobial activity of honey, Rivista di Biologia 94:363-371.

Conceicao T, Brizio A, Duarte A, Barros R. First isolation of blaVIM-2 in K.oxytoca clinical isolates from Portugal. Antimicrob. Agents Chemother 2005; 49: 476.

Cooper RA, Halas E, Molan PC. The efficacy of honey in inhibiting strains of Pseudomonas aeruginosa from infected burns. J Burn Care Rehabil 2002; 23: 366-370.

Cooper, R.A. (1999). Honey in wound care. J.Wound Care 8(7): 340.

Halcon L, Milkus K. Staphylococcus aureus and wounds: a review of tea tree oil

Kingsley A. The use of honey in the treatment of infected wound. British J Nursing 2001; 10: S13S16.

Kwakman PH, Te Velde AA, de Boer L, Speijer D, Vandenbroucke- Grauls CM, Zaat SA. How honey kills bacteria. FASEB J 2010, 24: 2576-2582.

Levy SB, Marshall B. Antibacterial resistance worldwide: causes, challenges and responses. Nat Med 2004; 10: 122-129.

Lusby PE, Coombes A, Wilkinson JM. Honey: A potent agent for wound healing? J Wound Ostomy Continence Nurs 2002; 29: 295-300.

Mandal S, Pal NK, Chowdhury IH, Deb Mandal M. Antibacterial combination, against Vibrio cholerae O1 biotype El Tor serotype Ogawa isolates. Polish J Microbiol 2009; 58: 57-60.

Miorin PL, Levy NCJ, Custodio AR, Bretz WA, Marcucci MC. Antibacterial activity of honey and propolis from Apis mellifera and Tetagonisca angustula against $S$. aureus. J. Applied. Microb 2003; 95: 913-92023). 85.19).

Mohrig,W. and Messner, R. (1968). Lysozym als antibacterielles agens im honig und bienengift. Acta Biologica Medica Germanica, 21:

Molan P. Not all honeys are the same for wound healing. Bull Eur. Tissue Rep.

Molan PC. 1992a. The antibacterial activity of honey. 1. The nature of the antibacterial activity.

Molan PC. The evidence supporting the use of honey as a wound dressing. Int $\mathbf{J}$ Low Extrem Wounds 2006; 5: 40-54.

Molan PC. The evidence supporting the use of honey as a wound dressing. Int $\mathbf{J}$ Low Extrem Wounds 2006; 5: 40-54. 
Moreno J, Cruz C, Renzoni A. Tracking methicillin resistant Staphylococcus aureus Colombian hospitals over 7 years (1996-2003): emergence of a new dominant clone. Int. J. Antimicrob Agents 2005; 25: 457-462.

New Zealand honeys. J Pharm Pharmacol 1991; 43: 817-822

Nzeako BC, Hamdi J. 2000. Antimicrobial potential of honey on some microbial isolates, Med. Sci., 2:7579.

pattern comparisons among bloodstream infection isolates from SENTRY Antimicrobial Surveillance Program. Diagn. Microbiol. Infect. Dis 2004; 50: 59-

Podschun R, Ullmann U. Klebsiella spp. As nosocomial pathogens: epidemiology, taxonomy, typing methods and pathogenecity factors. Clin Microbiol Review 1998; 11:589-603.

Simon A, Traynor K, Santos K, Blaser G, Bode U, Molan P. Medical honey for wound care - still the 'Latest Resort'. Evid Based Complement Alternat Med 2008; doi:10.1093/ecam/ nem175.

Soc 2002; 9: 5-6.

Taormina PJ, Niemira BA, Bauchat LR. 2001. Inhibitory activity of honey against foodborne pathogens as influenced by the presence of hydrogen peroxide and level of antioxidant power. Inter. J. Fd Microbiol., 69:217-225.

Taormina PJ, Niemira BA, Beuchat LR. Inhibitory activity of honey against food

Van den Berg AJ, Van den Worm E, Van Ufford HC, Halkes SB, Hoekstra MJ, Beukelman CJ. An in vitro examination of the antioxidant and antiinflammatory properties of buckwheat honey. J Wound Care 2008; 17: 172-178.

Wahdan HAL. 1998. Causes of the antimicrobial activity of honey. Infection 26(1):26-31.

Walsh SE, Maillard JY, Russel AD, Catrenich CE, Charbonneau AL, Bartolo RG.

Willix DJ, Molan PC, Harfoot CG. 1992. A comparison of the sensitivity of wound-infecting species of bacteria to the antibacterial activity of manuka honey and other honey. J. Appl. Bacteriol., 73(5):388-94.

Wiss Technol 1997; 30: 748-753. 